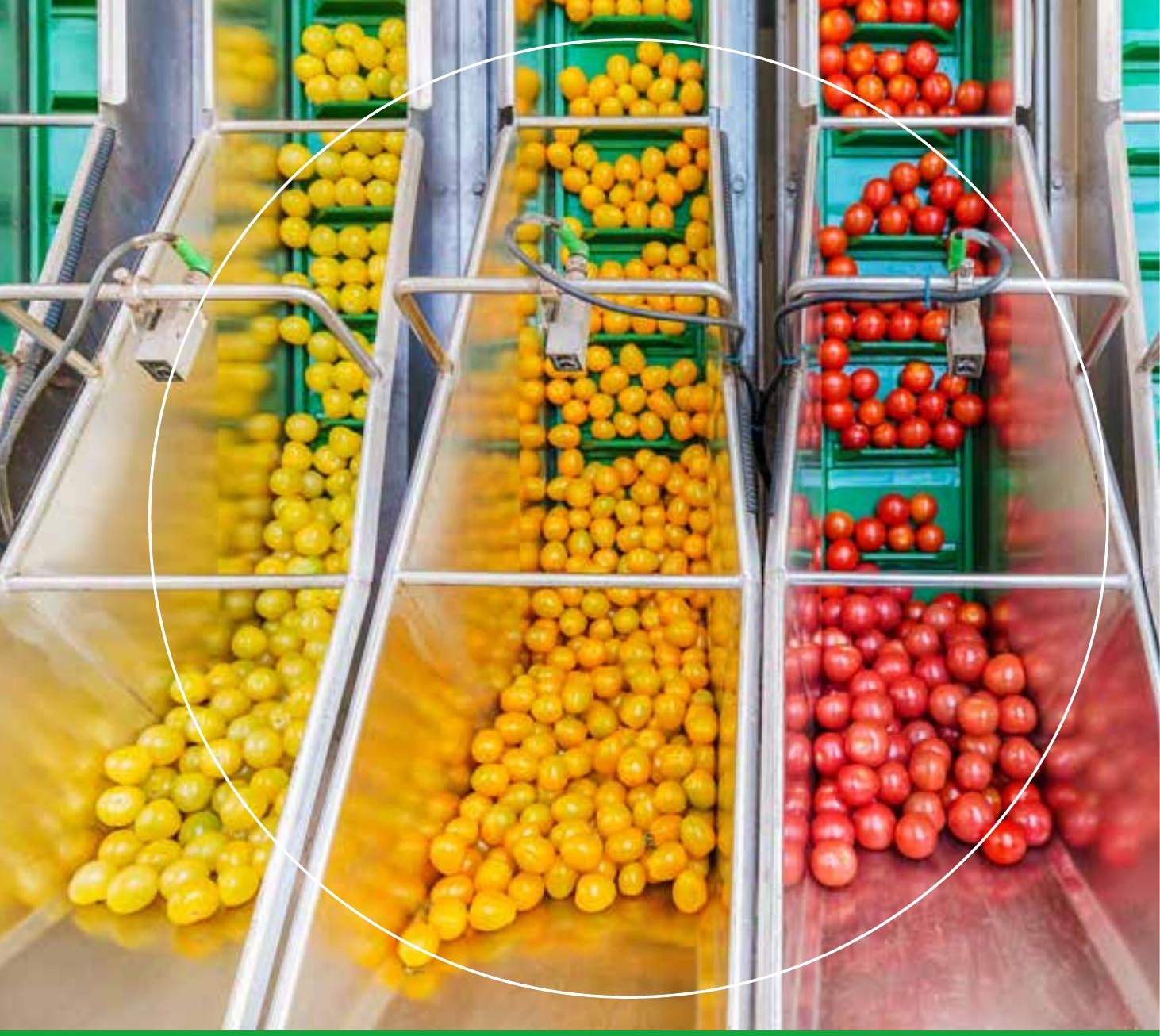

\title{
Food Economic Report 2019 of the Netherlands
}

Summary

H.A.B. van der Meulen and P. Berkhout

WAGENINGEN

UNIVERSITY \& RESEARCH 



\section{Food Economic Report 2019 of the Netherlands}

\section{Summary}

H.A.B. van der Meulen and P. Berkhout

This project was financed by the Dutch Ministry of Agriculture, Nature and Food quality from the public-private partnership 'Koepel Economische Informatievoorziening'.

Wageningen Economic Research

Wageningen, January 2020

BOOKLET 
Meulen, H.A.B. van der and P. Berkhout, 2020. Food Economic Report 2019 of the Netherlands; Summary. Wageningen, Wageningen Economic Research, Booklet. 20pp.; 0 fig.; 5 tab.; 4 ref.

This booklet provides an English summary of the Voedsel-Economisch Bericht 2019 and Duurzaamheid en inkomens in de land-en tuinbouw (www.agrofoodportal.com). It presents a survey of the economic state of Dutch agribusiness. Attention is paid to the development of the agricultural complex, the food industry, the retail chain and the consumption of food. The booklet then proceeds to describe the production structure in the primary agricultural sector, profitability and income formation as well as the environmental performance of the agricultural sector.

This publication can be downloaded at https://doi.org/10.18174/512109 or at www.wur.eu/economic-research (under Wageningen Economic Research publications).

(C) 2020 Wageningen Economic Research

P.O. Box 29703, 2502 LS The Hague, The Netherlands, T +31(0)70 33583 30, E communications.ssg@wur.nl, http://www.wur.eu/economic-research. Wageningen Economic Research is part of Wageningen University \& Research.

\section{(cc) BY-NC}

This work is licensed under a Creative Commons Attribution-Non Commercial 4.0 International License.

(C) Wageningen Economic Research, part of Stichting Wageningen Research, 2020

The user may reproduce, distribute, and share this work and create derivative works from it. Material by third parties which is used in the work and which are subject to intellectual property rights may not be used without prior permission from the relevant third party. The user must attribute the work by stating the name indicated by the author or licensor, but may not do this in such a way as to create the impression that the author/licensor endorses the use of the work or the work of the user. The user may not use the work for commercial purposes.

Wageningen Economic Research accepts no liability for any damage resulting from the use of the results of this study or the application of the recommendations contained in it.

Wageningen Economic Research is ISO 9001:2015 certified. Wageningen Economic Research Booklet | Project code 2282300260

Cover photo: Shutterstock 


\section{Contents}

$\begin{array}{ll}\text { Preface } & 4\end{array}$

1 The Dutch agricultural sector 4

1.1 The agricultural complex 5

1.2 Food and beverages industry 7

$\begin{array}{lll}1.3 & \text { Retail chain and food consumption } & 7\end{array}$

$\begin{array}{lll}1.4 & \text { Trade in agricultural products } & 10\end{array}$

2 The agricultural and horticultural sector $\quad 12$

2.1 Number of holdings 12

2.2 Labour, land, and capital 13

2.3 The sector's income 14

2.4 Environmental performance 15

$\begin{array}{ll}\text { References } & 19\end{array}$ 


\section{Preface}

This booklet provides a summary of two publications, the Food Monitor 2019 (Voedsel-Economisch Bericht) and Sustainability and income development of the primary agricultural sector 2019 (Duurzaamheid en inkomens in de land-en tuinbouw). Both publications have been commissioned by the Ministry of Agriculture, Nature and Food Quality.

The Food Monitor is the successor to the Annual Agricultural Report and offers a global survey of the Dutch food economy. Attention is paid to the development of the agricultural complex, the food industry, the retail chain and the consumption of food. Based on the Sustainability and income development of the primary agricultural sector report, this booklet then proceeds to describe the production structure in the primary agricultural sector, profitability and income formation as well as the environmental performance of the agricultural sector.

The full versions of both publications (in Dutch) are available online via www.agrofoodportal.com. Part of the information on this website is also available in English.

The Hague, January 2020

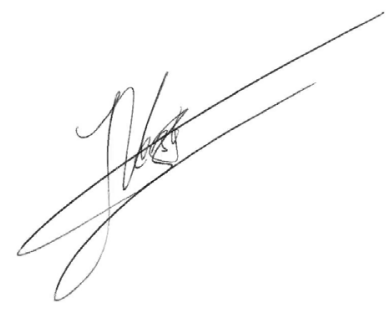

Prof.dr.ir. J.G.A.J. (Jack) van der Vorst

General Director Social Sciences Group (SSG)

Wageningen University \& Research 


\section{The Dutch agricultural sector}

\subsection{The agricultural complex}

The agricultural sector - comprising agriculture, horticulture and fisheries - is linked closely to other parts of the economy. For example, agricultural production is virtually impossible without provision of goods and services such as animal feed, fertiliser, energy, machinery, sheds, greenhouses, and veterinary and business services, whilst raw agricultural products require processing in the food industry, trade and distribution before they reach the consumers table. One can view the entire set of direct and indirect activities surrounding the agricultural sector as one inter-related chain, which we often refer to as the agro (or agricultural) complex.

In this approach the primary sector and the processing industry for food are the main focal point. The size of the agricultural complex is determined by what the primary sector and processing industry need from suppliers and logistics to create the products.

Agro complex delivers almost 7\% of the GDP (gross domestic product) In 2017 - the most recent year for which figures are available - the added value of the total agro complex amounted to approximately 51 billion euros. This means the total agro complex contributes $6.9 \%$ to the national gross domestic product (GDP). In 2010, the share in the national total was still $7.6 \%$ and has been fluctuating around the $7 \%$ mark since 2015.

In terms of added value, the arable complex is the most significant within the total agro complex. This is due to the large share of imports of coffee, tea, and cocoa, and of vegetable oils and fats. The import of animal feed raw materials is also allocated to the arable complex. The land-based livestock farming complex comes in second place. 
Employment in the entire agricultural complex has grown during recent years, reaching about 582,000 employment years in 2017 (Table 1), which represents $7.9 \%$ of the national total. Since 2010 , employment in the domestic raw materials-based agro complex has been fairly stable at around 400,000 work years.

Table 1 Gross value added and employment in the Dutch agricultural complex, 2010 and $2017^{a}$

\begin{tabular}{|c|c|c|c|c|}
\hline & $\begin{array}{l}\text { Added } \\
\text { value } \\
\text { ( } x \text { billion } \\
\text { euros) } \\
\end{array}$ & $\begin{array}{l}\text { Added } \\
\text { value } \\
\text { ( } x \text { billion } \\
\text { euros) } \\
\end{array}$ & $\begin{array}{l}\text { x 1,000 } \\
\text { annual } \\
\text { labour } \\
\text { units } \\
\end{array}$ & $\begin{array}{l}\text { x 1,000 } \\
\text { annual } \\
\text { labour } \\
\text { units } \\
\end{array}$ \\
\hline & 2010 & 2017 & 2010 & 2017 \\
\hline $\begin{array}{l}\text { Total - domestic, and imported } \\
\text { agricultural raw materials complex }\end{array}$ & 43.2 & 50.6 & 575.6 & 582.2 \\
\hline Share in national total (GDP) & $7.6 \%$ & $6.9 \%$ & $8.2 \%$ & $7.9 \%$ \\
\hline $\begin{array}{l}\text { Totals - imported agricultural raw } \\
\text { materials complex }\end{array}$ & 15.1 & 19.8 & 174.1 & 185.4 \\
\hline Share in national total & $2.7 \%$ & $2.7 \%$ & $2.5 \%$ & $2.5 \%$ \\
\hline $\begin{array}{l}\text { Total - domestic agricultural raw } \\
\text { materials complex }\end{array}$ & 28.1 & 30.8 & 401.5 & 396.7 \\
\hline Share in national total & $4.9 \%$ & $4.2 \%$ & $5.7 \%$ & $5.4 \%$ \\
\hline Primary production & 9.1 & 11.4 & 164.7 & 164.4 \\
\hline Processing & 4.2 & 5.2 & 54.7 & 64.5 \\
\hline Supply & 11.8 & 11.3 & 144.9 & 141.3 \\
\hline Distribution & 3.0 & 2.9 & 37.2 & 26.5 \\
\hline
\end{tabular}

a) The share of added value is calculated as a percentage of GDP and not as a percentage of the national added value.

Source: CBS (Statistics Netherlands) - processed by Wageningen Economic Research.

Export provides a significant contribution to gross value added (GVA) and employment in the agricultural complex An important part of the activities of the agricultural complex is associated with exporting processed and raw agricultural materials. Export contributes about three quarters of GVA and employment over the entire agricultural complex. Dependence on exports varies slightly 
for different parts of the agricultural complex, ranging from $72 \%$ for the arable farming sector to $85 \%$ in the greenhouse horticulture complex.

\subsection{Food and beverages industry}

Measured by sales and employment, the food industry is the largest branch of industry. In 2018, the number of companies in the food industry rose to 5,655; they offered employment to 102,000 people. Almost one in six industrial employees works in the food industry. The beverage industry included 730 companies in 2018 , with employment for 6,600 people. Several industrial sectors are included in these figures, from fruit and vegetable processing to abattoirs, meat products industry, bakeries, and baked goods. The tobacco industries are not included.

In recent years, the share of net food industry sales as a percentage of total industry has risen, but it fell from 21 to $20 \%$ in 2017 . In terms of net sales, the meat processing industry and the dairy processing industry are the largest sectors within the food industry, with shares of 16 and $20 \%$ respectively. The relative importance of the dairy industry has increased again after a decline in 2016.

\subsection{Retail chain and food consumption}

In 2018, the total foodstuff turnover through all sales channels in the Netherlands reached almost sixty billion euros (Table 2 ). That sum involves retail sales (supermarkets and other retail outlets, e.g. markets and specialised businesses), and the food service sector (hotels and restaurants, catering, leisure and sales points 'on the move').

The revenue from food and drinks in retail in 2018 represents around 40 billion euros. Of all food turnover in the retail trade, 30.7 billion euros is generated by supermarkets, making them the most important sales channel for food and drink. The food service sector accounts for almost a third of all sales. The shares of retail and food service are relatively stable. Together cafés, hotels and restaurants; the recreational sector; catering; 
and roadside sales points saw 20 billion euros in sales, an increase of 1 billion euros compared with 2017. The table below lists food and drink sales per type of sales channel. The boundaries between the types of sales channels have become increasingly blurred over the years. For instance, retailers in the food sector have greater opportunities to develop food service activities in their stores, and catering outlets are being set up in areas of stores. Supermarkets are selling more and more meals, and in some restaurants you can buy products. Sometimes the initiatives take things a step further by combining shops, restaurants and market stalls in 'market halls' or 'food halls'.

Table 2 Food and drink turnover in the Netherlands, 2017 and 2018, in billions of euros

\begin{tabular}{lrr} 
& 2017 & 2018 \\
Supermarkets & 30.5 & 30.7 \\
\hline Small retail and online retail (incl. temporary retail locations) a) & 8.6 & 8.9 \\
\hline Food service, b) of which & 19.1 & 20.1 \\
\hline Hospitality & 11.9 & 12.7 \\
\hline Sport and recreation c) & 1.3 & 1.4 \\
\hline Catering & 3.3 & 3.3 \\
\hline Roadside d) & 2.6 & 2.7
\end{tabular}

a) Online delivery service by supermarkets is, whenever possible, included in online retail.

b) Including online delivery service of meals.

c) Expenditures in sports facilities, recreation parks, amusement parks, etc.

d) Expenditures in petrol stations and catering in retail and (public) transport.

Source: Foodstep (food service), CBS (supermarkets), FSIN (other). Editing: Wageningen Economic Research.

The large supermarket chains such as Ahold Delhaize (Albert Heijn), Jumbo, Lidl, and Aldi buy independently, while the smaller chains are members of the wholesale purchasing cooperative Superunie. Superunie is a collective purchasing association encompassing mainly (but not exclusively) regional supermarket chains, and represents a $28 \%$ share of the supermarket purchasing market. Ahold/Delhaize tops the league for turnover and market share in the Netherlands. In 2018, Ahold/Delhaize realised more than 13 billion euros of turnover, Jumbo comes in a safe second, with a turnover of more than 7 billion euros. Together, Albert Heijn/AH ventures and Jumbo control $54 \%$ of the market. 
Increased household expenditure on food

In 2018, Dutch households spent around 324 billion euros on food, semi-luxury foods and beverages, tobacco, consumer durables, energy, water, fuel, and services, including hotels, restaurants, and catering. Over 47 billion euros was spent on food and semi-luxury foods (Table 3). From that sum, over 30 billion euros of the expenditure was on foodstuffs, e.g. dairy products, meat, and fish, potatoes, vegetables and fruit, and bread. The remaining expenditure was on semi-luxury items such as ice creams, candies, beverages and tobacco. Expenditure on food, semi-luxury foods, beverages and tobacco amounted to $14.6 \%$ of total consumer spending on goods and services in 2018. In the long term, this share is set to decrease slightly (Table 3). Expenditure on food in catering and leisure is included in those for services and is not indicated in this section.

Table 3 Household consumer expenditure (billions of euros) (a) 2014-2018

\begin{tabular}{|c|c|c|c|c|c|}
\hline & 2014 & 2015 & 2016 b) & 2017 b) & 2018 b) \\
\hline Foodstuffs & 27.0 & 27.8 & 28.5 & 29.3 & 30.3 \\
\hline $\begin{array}{l}\text { Semi-luxury foods, } \\
\text { beverages, and tobacco c) }\end{array}$ & 15.7 & 15.9 & 16.1 & 16.4 & 17.0 \\
\hline $\begin{array}{l}\text { Total on food and semi- } \\
\text { luxury items d) }\end{array}$ & 42.7 & 43.7 & 44.6 & 45.8 & 47.3 \\
\hline $\begin{array}{l}\text { Total consumer expenditure } \\
\text { on goods and services }\end{array}$ & 287.5 & 294.1 & 300.4 & 310.3 & 323.8 \\
\hline $\begin{array}{l}\text { Share (\%) foodstuffs and } \\
\text { semi-luxury foods, drinks, } \\
\text { and tobacco }\end{array}$ & 14.9 & 14.9 & 14.8 & 14.7 & 14.6 \\
\hline
\end{tabular}

a) Compared to actual prices.

b) The expenditure in euros is calculated on the basis of published indices and changes in value.

c) Including tobacco. According to the tobacco retail trade association, spending on tobacco in 2016 was more than 4.2 billion euros.

d) Relates to spending by consumers through trade or directly. Expenditure in hospitality and catering is not included.

Source: CBS - processed by Wageningen Economic Research. 
Consumption of foodstuffs from sustainable and organic production continuous to grow

Total consumer spending on sustainable food amounted to 4.9 billion euros in 2018: an increase of $7 \%$ when compared with 2017 . The share of sustainable food within the total food spending was $11 \%$ in 2018. Across all product groups, consumers have more often chosen to include an organic product as part of their basic groceries in recent years. Products which are produced under other sustainability certification systems, such as Beter Leven (quality label for animal welfare), UTZ Certified, Fair Trade, Aquaculture Stewardship Council (ASC, a quality label for farmed fish) and On the way to Planet Proof also account for an increasing proportion of the range.

\subsection{Trade in agricultural products}

Agricultural goods exports reach new record level

The volume of Dutch agricultural exports for 2019 is estimated at 94.5 billion euros. This is $4.6 \%$ more than the final figure for 2018 ( $€ 90.4$ billion) and a new record. The growth in export value is mainly due to an increase in export prices and, to a lesser extent, to growth in export volume. In 2018, the Netherlands is again the second largest agricultural exporter in the world, after the United States of America (USA). Germany, Brazil, and China round out the top 5 of the most important export countries for 2018. A striking difference between the countries is that, in this top 5, Brazil and the Netherlands are net exporters, while the United States, Germany, and especially China import more than they export. Brazil is actually the largest net agricultural exporter in the world, followed by the Netherlands and Argentina. Thailand and New Zealand completed the top 5 of the most important net agricultural exporter countries in the world (Jukema et al., 2020).

In 2019 , about $77 \%$ of Dutch agricultural exports went to EU countries. This percentage has remained fairly constant in recent years. Germany, Belgium, the United Kingdom, and France accounted for approximately $54 \%$ of the exports. The most important export products are flowers and plants, live animals and meat, dairy and eggs, vegetables and fruit. 
Import value of agricultural products in the Netherlands increases Imports in 2019 are estimated at 64.1 billion euros, which is $3.7 \%$ higher than the final figure of 2018 (61.8 billion euros). The share of imports from EU countries has remained fairly stable at around $60 \%$. The most important source countries for imports from within the EU are Germany, Belgium, France, and Spain. The main import source countries outside the EU are Brazil, the United States (soy), and Ukraine (grain) (Jukema et al., 2020). 


\section{The agricultural and horticultural sector}

\subsection{Number of holdings}

The number of agricultural and horticultural companies fell by more than 900 , to 53,900 in 2018 , a decrease of $1.7 \%$ (Table 4 ). That is less than the long-term average of $2 \%$ to $3 \%$ per year. In 2016 , due to changes in the registration of the agricultural and horticultural companies, the number of farms saw a sharp one-time decline (13\%). The most important change is that companies not listed in the trade register (Chamber of Commerce) with agrarian activity, are no longer included in the agricultural census.

Table 4 Developments in the numbers of holdings and employees, and total area of farmland from 2000 onwards

\begin{tabular}{lrrrrr} 
& 2000 & 2005 & 2010 & 2017 & 2018 \\
$\begin{array}{l}\text { Number of agricultural and } \\
\text { horticultural farms (x 1,000) }\end{array}$ & 97,389 & 81,750 & 72.324 & 54,840 & 53,906 \\
\hline Number of workers (x 1,000) & 280.9 & 235.7 & 212.0 & 170.4 & 176.1 \\
\hline Area of farmland (x 1.000 ha) & $1,975.5$ & $1,937.7$ & $1,872.3$ & $1,818.6$ & $1,822.4$ \\
\hline
\end{tabular}

Source: CBS (Statistics Netherlands) agricultural census, processed by Wageningen Economic Research.

In horticulture, the fall in the number of farms - $7 \%$ in greenhouse horticulture and almost 3\% in open-field horticulture - corresponds to the average reduction since 2000 . The slight increase in the number of arable farms in 2018 is probably partly due to the influx from dairy farming. The number of dairy farms fell by more than $5 \%$ in 2018 , mainly due to measures to reduce phosphate production in the dairy sector. After years of falls in the number of intensive livestock farms by an average of more than $4 \%$, the number of farms remained virtually the same in 2018. This may have been caused in part by waiting for the 
implementation of the rationalisation scheme for pig farming in combination with the improved market situation.

\subsection{Labour, land, and capital}

The total number of persons regularly employed in the primary agricultural and horticultural sector increased by 5,700 to just over $176,000(+3.4 \%)$ in 2018 (Table 4). This means a break in the virtually continuous decline in the number of workers by an average of $3 \%$ between 2000-2017. In 2016 there was a sharp reduction in the number of workers $(-23,000$ or $-7 \%)$, mainly due to changes in the registration of farms and nurseries.

Around $70 \%$ of the permanent workers are part of the family In 2018 , more than 122,000 of the regularly employed (permanent) labour force are family members (farmers, spouses and other coworking family members), i.e. $69 \%$. This is slightly ( 2 percentage points) lower than in 2016 and 2017. In 2018, the number of non-family workers (also described as staff) increased by $7.7 \%$ to almost 54,000 under the effects of economic growth. These figures do not include flexible labour (temporary workers from agencies and personnel with short-term contracts). The regular employees usually have full-time jobs all year round, while flexible employees, particularly in the open-field horticulture sector, only come in for peak periods. This makes it difficult to determine, or even estimate, the number of flexible workers. In the harvest/peak periods, although large numbers of people may be at work, this is only for short/very short periods.

\section{Use of agricultural area}

Farms and nurseries had agricultural area of 1.82 million ha in use in 2018, slightly more than in 2017 (Table 4). Over a somewhat longer period (2000-2015), the agricultural area in use fell by an average of $0.5 \%$ per year. Of the total area of cultivated land, $54 \%$ is now in use as grassland (permanent, temporary and natural), $12 \%$ for green fodder crops, $28 \%$ for other arable production, $5 \%$ for open-field horticulture and $0.5 \%$ for greenhouse horticulture. 
Balance sheet value of agriculture and horticulture 3.5 million euros in 2018

The balance sheet value of the farms and nurseries at the end of the financial year increased to an average of more than 3.5 million euros per farm in 2018. Compared to 2017, this meant an increase in value of approximately 0.5 million euros. The introduction of phosphate rights for dairy farming is an important reason behind this. The increase in the value of land and economies of scale have also contributed to the rising balance sheet value. Long-term debts remain stable, to an average of 800,000 euros per farm.

Since the beginning of this decade (2010), the average book value of agricultural and horticultural holdings increased by around 1.0 million euros, mainly due to introduction of phosphate rights in 2018 in the dairy sector, increased average farm size and higher farmland prices. In the same period the solvency rate (part that is financed with in-house capital) increased from $67 \%$ to $73 \%$. By the end of 2018 , the land represented $51 \%$ of the total balance-sheet value, compared to $46 \%$ in 2010 .

\subsection{The sector's income}

The average farm income for agricultural and horticultural businesses in 2019 is estimated at around 57,000 euros per unpaid annual work unit (AWU). That represents an increase of 6,000 euros compared to 2018 . The income is also higher than the multiannual average of 52,000 euros over the period 2014-2018. The increase is mainly due to pig farming and horticulture (including greenhouse horticulture). Arable farmers have to contend with lower prices, which reduces their incomes. Dairy farmers are also seeing their incomes fall as a result of higher costs and lower yields. Each year the agriculture and horticulture sector sees significant differences in income, both within a given sector and among the various sectors.

Pig farmers benefit from significantly higher prices for piglets and fattening pigs. While ${ }^{1}$ incomes in 2018 were only just above zero, in

1 Income $=$ income from business per unpaid annual work unit 
2019 they rose to a historically high level of around 250,000 euros on average as a result of increased demand for Dutch pork, thanks to reduced production in Asia as a result of an outbreak of African swine fever. Dairy farmers' income ${ }^{1}$ fell to an average of 31,000 euros due to higher costs of feed, buildings and machinery. Arable farmers have seen their income ${ }^{1}$ for the 2019 harvest year halved to 37,000 euros compared with the above-average good income year of 2018. The reason for this is lower prices for most crops due to higher yields per $\mathrm{kg}$ and slightly increased costs. In the greenhouse nursery sector, incomes ${ }^{1}$ in both greenhouse vegetables and cut flowers rose to around 290,000 and 170,000 euros due to a recovery in tomato and pepper prices, higher prices for cut flowers and lower energy costs. The income ${ }^{1}$ of growers of pot and bedding plants is estimated to be considerably lower in 2019 at around $€ 130,000$.

While in 2017 the average farm and nursery received its first marketbased payment for using of its own labour and equity, in 2019 profitability will be 99 euros of income per 100 euros of costs.

\subsection{Environmental performance}

The environmental impact of the primary agriculture and horticulture sector is visible and measurable through different environmental indicators. There is wide ranging variation between developments connected with each environmental issue.

The agricultural sector is the main source for the emission of ammonia; ammonia is released in stables and in the use and storage of manure and fertiliser. The ammonia emissions from stables and in the storage of animal manure make up the lion's share of ammonia emissions. Since 2010, ammonia emissions are virtually stable at a level of around 110-115 million $\mathrm{kg}$ (Table 5). For the $2020-2030$ period, a $13 \%$ decrease in ammonia emissions from all sources has been agreed in the EU when compared to 2005 (134 million $\mathrm{kg}$ ). This objective has already been achieved. 
Table 5 Development of the environmental impact of agriculture and horticulture, 2000-2017

\begin{tabular}{lccccr} 
& 2000 & 2005 & 2010 & 2016 & 2017 \\
$\begin{array}{l}\text { Use of crop protection } \\
\text { agents (in million kg of } \\
\text { active substance) }\end{array}$ & 9.644 & 9.309 & 9.288 & 9.511 & 9.695 \\
\hline $\begin{array}{l}\text { Greenhouse gas emissions } \\
\text { (in billion } \mathrm{CO}_{2} \text { equivalents, }\end{array}$ & 28.5 & 26.1 & 29.5 & 28.0 & 28.2 \\
\begin{tabular}{l} 
IPPC2013) \\
\hline $\begin{array}{l}\text { Surplus of nitrogen (N, kg } \\
\text { per hectare) }\end{array}$
\end{tabular} & 183 & 142 & 114 & 133 & 126 \\
$\begin{array}{l}\text { Surplus of phosphates ( } \mathrm{P}_{2} \mathrm{O}_{5}, \\
\text { kg per hectare) }\end{array}$ & 52 & 36 & 27 & 12 & 5 \\
\hline $\begin{array}{l}\text { Ammonia emissions (in } \\
\text { million kg) }\end{array}$ & 158 & 134 & 116 & 110 & 114 \\
\hline
\end{tabular}

Sources: Nefyto - RIVM (Dutch National Institute for Public Health and the Environment)/CBS, Milieucompendium (Environment Compendium), various years.

Pesticide sales have been fluctuating at around 10 million $\mathrm{kg}$ of active ingredient per year. In 2017, volume increased from 9.5 to 9.7 million $\mathrm{kg}$; an increase of $2 \%$. Over $40 \%$ of the products used are fungicides and $30 \%$ herbicides (including glyphosate). Fluctuations in usage are closely related to the weather. In years with damp summers, for example, fungal outbreaks are more severe than in dry years. Although 2017 was very warm and very sunny, it was also wetter than usual. A cold and, consequently, slow start to the cultivation season also affects the use of crop protection agents, as this retards the development of diseases and infestations. Around $98 \%$ of total pesticide sales were for use in agriculture and horticulture. Retail users or public park and garden managers used the remainder. These are often herbicides.

In addition to use in absolute quantities, the environmental impact of the products used per $\mathrm{kg}$ of active ingredient is a significant indicator. The environmental impact of arable farming has been halved in the period 2007-2017 due to the ongoing remediation of relatively harmful substances.

Greenhouse gas emissions have fallen sharply since 1990 but they have remained fairly stable in recent years. In 2017, emissions were slightly 
higher than in 2015 and 2016 (Table 5). The share of agriculture and horticulture in total greenhouse gas emissions in the Netherlands is around 12 to $14 \%$.

Greenhouse horticulture is subject to the Long-Term Energy Transition Agreement for Greenhouse Horticulture 2014-2020 (Ministry of Economic Affairs, 2014). The original $\mathrm{CO}_{2}$ target (6.2 megatonnes in 2020) was tightened to 4.6 megatonnes in 2017 due to shrinking glass acreage and reduced electricity sales. At 5.7 megatonnes in 2018, total $\mathrm{CO}_{2}$ emissions from greenhouse horticulture are at the 2014 level and 1.1 megatonnes above target. The expectation is that the target will not be met. $\mathrm{CO}_{2}$ emissions fell considerably in the 2010-2014 period. This was primarily due to a reduction in acreage, reduced electricity sales and lower energy consumption per $\mathrm{m}^{2}$ of greenhouse. Since 2014, increasing energy consumption per square metre and greater electricity production for sale have led to an increase in $\mathrm{CO}_{2}$ emissions (Van der Velden \& Smit, 2019).

In the coalition agreement of 2017, the Cabinet announced measures to implement the national reduction target for greenhouse gas emissions. It was also agreed in the coalition agreement that there would be a Climate Agreement. More than 100 parties have worked on a coherent package of proposals to achieve the $\mathrm{CO}_{2}$ reduction target by 2030 . The Climate Agreement was presented on 28 June 2019. The Climate Accord also requires agriculture and horticulture to play their part in reducing greenhouse gas emissions. This will involve using different and modified agricultural methods (smarter land use), energy savings in greenhouse horticulture and a reduction in methane emissions from livestock farming (Berkhout et al., 2019). The Cabinet has set the agriculture and land use sectors the target of achieving an additional reduction of 3.5 megatonnes in greenhouse gas emissions by 2030 (on top of existing policy).

There has been a strong reduction in surpluses of nitrogen and phosphate per hectare as a consequence of the export of manure, a reduction in the use of artificial fertiliser and lower phosphate levels in feed and thus in manure (Table 5). The total production of phosphate and nitrogen is subject to a fixed ceiling; the excretion of nutrients must 
not exceed 173 million $\mathrm{kg}$ of phosphate and 504 million $\mathrm{kg}$ of nitrogen (including gaseous losses) in any one year. In 2015 and 2016 the limit for phosphate was exceeded, due mainly to higher phosphate production in dairy farming. In 2017, the amount of phosphate in animal manure was again be lower than the limit set by the EU, thanks to the measures taken to reduce phosphate production in dairy farming. In 2018, phosphate production fell further to 162 million $\mathrm{kg}$, which was mainly due to a decline in dairy farming.

In 2017, nitrogen production exceeded the limit for the first time, at 512 million $\mathrm{kg}$. In 2018, nitrogen production from Dutch livestock once again fell to 504 million $\mathrm{kg}$, i.e. to the exact level of the set limit. This reduction is attributable to grazing livestock, due to a fall in the number of dairy and veal cows and young cattle. 


\section{References}

Berkhout, P., A. van Doorn, H. van der Meulen, G. Tacken, G. Venema, T. Vogelzang (2019). De landbouw en het landelijk gebied in Nederland in beeld - een houtskool-schets van de SWOT voor het GLB. Wageningen, Wageningen Economic Research, Rapport 2019-058.

Jukema, G.D., P. Ramaekers en P. Berkhout (Red.), 2020. De Nederlandse agrarische sector in internationaal verband. Wageningen/Heerlen/Den Haag, Wageningen Economic Research en Centraal Bureau voor de Statistiek, Rapport 2020-001.

Ministery of Economic Affairs (2014). Meerjarenafspraak Energietransitie Glastuinbouw 2014-2020.

Van der Velden, N.J.A. en Smit, P.X. (2019). Energiemonitor van de Nederlandse glastuinbouw 2018, Rapport 2019-111 Wageningen Economic Research. 

The mission of Wageningen University and Research is "To explore the potential of nature to improve the quality of life". Under the banner Wageningen University \& Research, Wageningen University and the specialised research institutes of the Wageningen Research Foundation have joined forces in contributing to finding solutions to important questions in the domain of healthy food and living environment. With its roughly 30 branches, 5,000 employees and 12,000 students, Wageningen University \& Research is one of the leading organisations in its domain. The unique Wageningen approach lies in its integrated approach to issues and the collaboration between different disciplines.

Wageningen Economic Research

P.O. Box 29703

2502 LS Den Haag

The Netherlands

E communications.ssg@wur.nl

www.wur.eu/economic-research

\section{BOOKLET}

